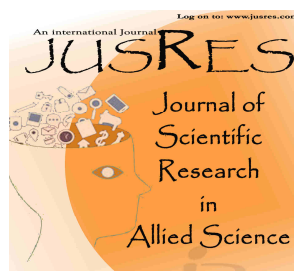

ISSN No. 2455-5800

Journal of Scientific Research in Allied Sciences

Original Research Article

\title{
INSTITUTIONAL CARE AND PROBLEMS OF THE ELDERLY
}

\author{
Dr. Abdul Wahab Pathath
}

Assistant Professor, Department of Clinical Neurosciences, College of Medicine

King Faisal University, Al Ahsa, Saudi Arabia.

Article history:

Submitted on: October 2017

Accepted on: October 2017

Email: info@jusres.com

\begin{abstract}
Each gray hair can be considered as the reservoir of knowledge and experience. The brightness of the gray hair reflects the vast and wide knowledge that a person acquired throughout his life. The eyes of old people can visualize the pros and cons of happenings. Senior citizens are really the guide to the younger generation. It is our duty to make their "evenings" peaceful, pleasant and memorable.
\end{abstract}

\section{KEYWORDS: Problems of the elderly, Institutional Care, Aging.}

\section{INTRODUCTION}

Aging is a social problem and is often studied from the point of view of one or more of the basic perspectives. From the functionalist perspective, aging is a problem because institutions of modern societies are not working well enough to serve the needs of the dependent aged. The extended families which once allowed elderly people to live out their lives among kin have been weakened by greater sociomobility and a shift to the nuclear family as the basic kinship unit. As grandparents, for example, once played an important role in socializing the young, teaching them the skills, values, and ways of life of their people. Now, these functions are performed by schools and colleges, for it is assumed that the elderly cannot understand or master the skills required in today's fast-changing world. Instead, they most often are cared for either at home or institution such as old age homes, which free the productive member of society to perform other functions. 
Interactionists view the term elderly as a stigmatizing level that suggests that older people are less valuable because they do not conform to the norms of a youth-oriented culture. Interactionists view the elderly as victims of ageism- a form of prejudice and discrimination directed at the aged not only by individuals but also by entire social institutions.

Conflict theorists view the problems of the elderly as stemming from their lack of power to shape social institution to meet the needs of people who are no longer in their productive year and have not accumulated the means to preserve their economic and social independence.

Bhattacharyya (1995) outline several problems of the aged such as finance, physical security, loneliness, isolation etc. Moreover, loss of status, the prevalence of corruption and indiscipline in various spheres of life create frustration and mental tension in them. The old age diseases like falling eyesight and hearing capacity, slow and faultering steps, declining energy, forgetfulness etc. make their life all the more miserable. Falling health and sickness, nutritional deficiencies and poor housing facilities affect their physiological and economic condition. The physio-social and environmental problems create a feeling of neglect, loss of importance in the family, feeling of unwantedness and inadequacy etc. Elderly become intolerant, short-tempered, sentimental, rigid and suspicious when they lose friends, spouse, power, influence, income, and health. Thus, their psychological makeup makes their living and adjustment in society more problematic. Poor health, economic dependence and nonworking status tend to create among them a feeling of dependency and powerlessness. The elderly in rural areas are worse off than those in urban areas. The gradual breakdown of the joint family system and consequent separation and migration of earning members in distant urban areas are other important aspects of the problem. As such, there is a total lack of security, affection and mental satisfaction and they are left alone to face the problems of the advancing age.

Bhattacharyya (1995) classified old people into two categories: (1) Those who have retired from an active service and are in receipt of pensions and other benefits. They do not generally suffer from financial constraints. They are in need of social support. (2) The other category is those who are poor. These people continue to work as long as they are physically capable and retire when the advancing age has a full grip on them. They are often deprived of family support and left to themselves. A sense of insecurity and helplessness persist throughout the remaining days of their lives. Economic and social security is necessary for this category of people. 
Old age brings ill-health, physical and sensory impairments, heightened sensitivity and increased susceptibility to disease (Birren \& Renner, 1977; Jamuna \& Ramamurti, 1990). Sensory and bodily impairments bring about varying amounts of disability too. They interfere with the day-to-day activities and self-help behavior of the elderly in differing degree, making the elderly dependent on others.

\section{INSTITUTIONAL CARE}

It is the duty of the society to provide comfort, medical care and happiness to the old persons who are without family care. The lonely, desperate grandfathers and grandmothers really need our attention and care. The opinion and suggestion of the aged people are precious to the society because they originate from the totality of their experience and knowledge, which they acquired from various fields. But many people do not lend their ears to the aged. A few even ignore the old people and do not give due respect and care to them.

Just a few decades back, in the majority of cases, the institution of the family was enough to take care of their aged. Urbanization, industrialization, and modernization have, however, brought about exogenous as well as endogenous changes in the family system. Because of the ever-growing economic difficulties, the newer concepts of small-sized nuclear families have emerged and the idea of 'joint families' living under one roof is breaking down. The tendencies amongst the younger lot are growing wherein it is argued that the care of an older member of the 'family' is not their responsibility. The values of life are increasingly becoming individualistic wherein the conjugal type of family, that is, the married couples and their unmarried children, offer limited care for older people (Amesur, 1959).

In recent past, the family was looked upon as the only institution to take care of the elderly and provide both emotional and financial support to them. But changes in the living arrangements and family structure, migration of children for jobs outside, and more prominently, radical changes in the nature of people from accommodative to an independent, self-centered, and individualistic outlook with callous concern for even very near relations, have compelled many old people to live alone.

Institutional services for older persons are not new. In the second half of the nineteenth century, charity experts began categorizing the poor and moving people into specialized institutions. Those judged to be lunatics were confined to asylums for the insane. Destitute children were placed in orphanages. Homes for the deaf and blind were established (Rosenberg, 1987). As other categories of paupers were moved into specialized institutions, the almshouses increasingly became de facto old age homes for the impoverished elderly. By 
the end of the nineteenth century, one-third of almshouse residents were aged; by 1923, 67 percent were (Haber \& Gratton, 1994).

Charitable religious organizations have been managing homes for the elderly for centuries. These services have now been expanded considerably in the voluntary sector. There are three types of Old Age Homes: (a) state-run homes, (b) homes run by a voluntary organization with financial help from the government, (c) paid Old Age Homes which do not receive any financial assistance from the government and charge from the elderly. These homes are catering mainly to the affluent /upper class elderly. In some homes the old age pension received by the aged is taken as charges towards their expenses and, therefore, they are a financial need to be based and are partially subsidized. Old people consider shifting to old age homes as the last option (Tandon, 2001). Prasad (1987) also opined that in India the elderly would hardly like to live separately unless forced by circumstances. Old Age Homes no doubt have contributed in providing shelter and homelike environment for the destitute and the needy persons but researchers have amply proved that these are no substitute for family care. (Tandon, 2001.)

\section{REFERENCE}

1. Bhattacharyya, S.K. (1995). Problems of the aged. Employment News, 1-7, 79.

2. Birren, J.E., \& Renner, V.J. (1977). Research on the Psychology of Aging: Principles and Experimentation. In J. E. Birren \& K. W. Schaie (Eds.), Handbook of Psychology of Aging (pp.3-35). New York: Van Nostrand Reinhold Co.

3. Jamuna, D., \& Ramamurthi, P.V. (1990). Old Age disability scale. Journal of Psychometry, 3, 21-26.

4. Amesur, C.A. (1959). Welfare Service for the aged and the Infirm. Indian Hospital System. New York: Basic Books.

6. Haber, C., \& Gratton, B. (1994). Old age and the search for security. Bloomington, IN Indiana University Press.

7. Tandon, S.L. (2001). Senior Citizens: $a$ perspective for the new millennium. New Delhi: Reliance publishing house.

8. Prasad, R. (1987). Problems of the aged in India - Some Reflections. In M.L Sharma \& T.M. Dak (Eds.), Aging in India: Challenges for the Society (pp. 33-39). New Delhi: Ajanta Publications.

Journal of Social work, 20, 157-162.

5. Rosenberg, C. (1987). The Care of

Strangers: The Rise of America's 